\title{
PENERAPAN CHATBOT AUTO REPLY PADA WHATSAPP SEBAGAI PUSAT INFORMASI PRAKTIKUM MENGGUNAKAN ARTIFICIAL INTELLIGENCE MARKUP LANGUAGE
}

\author{
Dimas Fajar Ramadhan, Sidik Noertjahjono, Joseph Dedy Irawan \\ Program Studi Teknik Informatika S1, Fakultas Teknologi Industri \\ Institut Teknologi Nasional Malang, Jalan Raya Karanglo km 2 Malang, Indonesia \\ 1618049@scholar.itn.ac.id
}

\begin{abstract}
ABSTRAK
Kepopuleran AI (Artificial Intelligence) semakin meningkat dari tahun ke tahun, dimulai di bidang medis, bisnis, akademik sampai hiburan tak luput dari peran sebuah Artificial Intelligence didalamnya. Tujuan dari penelitian ini adalah untuk membantu memudahkan Asisten Laboratorium dalam melakukan rekapitulasi data yang berhubungan praktikum pada Jurusan Teknik Informatika S-1 Institut Teknologi Nasional Malang, sekaligus untuk meningkatkan kualitas pelayanan yang bisa diberikan kepada para mahasiswa.

Pada penelitian ini, dibuat sebuah sistem yang melibatkan sebuah website Sistem Informasi Laboratoriumoratorium sebagai media untuk mengatur nilai dan informasi tentang praktikum, dan sebuah ChatBot dengan menerapkan Artificial Intelligence Markup Language sebagai sebuah virtual assistant yang menjebatani antara informasi dari database dengan mahasiswa. Dimana ChatBot ini selain bisa merespon percakapan, ia juga bisa mengambil data berupa nilai ataupun informasi yang ada di Praktikum. Sistem yang dirancang menggunakan bahasa pemrograman PHP, Javascript, Python, $P D O$ dan $M y S Q L$ sebagai databasenya.

Hasil pengujian sistem menunjukkan bahwa website Sistem Informasi Laboratoriumoratorium berfungsi dengan baik dalam mengelola (Create, Read, Update dan Delete) data mahasiswa, nilai, kelompok, aslab dan data lainnya. Sedangkan pada pengujian ChatBot menunjukkan bahwa program bisa merespon pesan yang dikirim melalui WhatsApp, mulai dari sekedar percakapan kosong sampai men-request informasi dari database.
\end{abstract}

Kata kunci : Artificial Intelligence, AIML, ChatBot, NLP, Virtual Assistant, Sistem Informasi.

\section{PENDAHULUAN}

Pada Lembaga Pendidikan Institut Teknologi Nasional yang berlokasikan di kota Malang, terdapat kegiatan wajib tiap semester yang harus dilaksanakan oleh para Mahasiswa yang disebut Praktikum. Praktikum normalnya dilaksanakan di laboratorium. Khususnya di Fakultas Teknik Informatika S-1, terdapat total 5 laboratorium yang aktif tiap semesternya untuk menjadi tempat praktikum. Asisten Lab di masing-masing laboratorium bertanggung jawab dalam melakukan kegiatan mengajar sekaligus mengurus penilaian, absensi, asistensi laporan dan kegiatan-kegiatan lain yang bersifat membimbing praktikan. Dalam kegiatan rekapitulasi nilai, seorang Aslab masih menggunakan cara manual yaitu mencatatnya pada kertas. Nilai praktikum didapatkan dari pengumpulan tugas yang diberikan tiap minggunya, dan juga didapat dari Keaktifan yang didapat selama kegiatan praktikum berlangsung. Pernah terjadi sebuah kejadian dimana praktikan meminta untuk mengkonfirmasi apakah tugas miliknya sudah lengkap, yang mana setelah di cek belum ada pencatatan dan mengharuskan aslab untuk mencari berkas yang terkait.

Disisi lain kepopuleran Kecerdasan Buatan semakin meningkat dari tahun ke tahunnya. Kecerdasan buatan adalah kecerdasan yang ditambahkan kepada suatu sistem yang bisa diatur, bisa juga disebut Artificial Intelligence atau hanya disingkat $\quad A I, \quad$ didefinisikan sebagai kecerdasan entitas ilmiah. Para ahli mendefinisikan kecerdasan buatan sebagai "kemampuan sistem untuk menafsirkan data eksternal dengan benar, untuk belajar dari data tersebut, dan menggunakan pembelajaran tersebut guna mencapai tujuan dan tugas tertentu melalui adaptasi yang fleksibel". Kecerdasan diciptakan dan dimasukkan ke dalam suatu mesin (komputer) agar dapat melakukan pekerjaan seperti yang dapat dilakukan manusia. Beberapa macam bidang yang menggunakan kecerdasan buatan antara lain sistem pakar, permainan komputer (games), logika fuzzy, jaringan saraf tiruan dan robotika.

Dengan ketidakefisienan kinerja dari sistem rekapitulasi nilai, dimana hampir semua kegiatan masih bersifat manual, seperti pengisian ataupun pengecekan nilai yang masih menggunakan kertas, begitupun dengan aliran informasi antara aslab dengan praktikan yang tidak bisa selalu terjalin selama Jam kerja. Ditambah dengan sedang naiknya sebuah Kecerdasan Buatan di dunia Teknologi, dengan pondasi dua poin tersebutlah, penulis ingin membangun sebuah sistem yang melibatkan sebuah ChatBot yang berperan sebagai Customer Service dimana ChatBot tersebut akan memberikan informasi praktikum yang dilaksanakan di laboratorium pada Fakultas Teknik Informatika di Institut Teknologi Nasional, ChatBot tersebut juga bisa digunakan sebagai kotak kritik \& saran, dan semua fasilitias tersebut bisa diakses melalui Aplikasi WhatsApp. Dan 
ChatBot tersebut akan terintegrasi dengan Sistem Informasi Laboratorium yang menampung informasi praktikum, mahasiswa, nilai dan asisten laboratorium yang bisa diolah secara langsung oleh asisten laboratorium.

\section{TINJAUAN PUSTAKA}

\subsection{Penelitian Terdahulu}

Kecerdasan Buatan adalah salah satu cabang Ilmu pengetahuan berhubungan dengan pemanfaatan mesin untuk memecahkan persoalan yang rumit dengan cara yang lebih manusiawi. Kecerdasan Buatan (Artificial Intelligence) merupakan salah satu bagian dari ilmu komputer yang mempelajari bagaimana membuat mesin (komputer) dapat melakukan pekerjaan seperti dan sebaik yang dilakukan oleh manusia bahkan bisa lebih baik daripada yang dilakukan manusia [1]. Sistem Kecerdasan buatan dilakukan analisa tingkat efektivitas proses pembelajaran dengan membandingkan beberapa indikator-indikator [2]. Salah satu aplikasi yang menggunakan kecerdasan buatan (Artificial Intelligence) adalah aplikasi ChatBot. ChatBot dikategorikan sebagai pemrosesan bahasa alami atau natural language yang merupakan salah satu bidang kecerdasan buatan yang melakukan pengolahan bahasa alami agar pengguna dapat berkomunikasi dengan komputer menggunakan bahasa sehari-hari [3]. Aktivitas kerja sekarang semakin membutuhkan media komunikasi yang cepat yang melahirkan fasilitas komunikasi secara realtime, sehingga dibutuhkan peran ChatBot dalam memberikan Informasi [4].

Bermodalkan teknik QnA, Question-Answering System dalam bentuk ChatBot menggunakan Artificial Intelligence Markup Language dapat berkomunikasi dan menyampaikan informasi [5]. ChatBot dapat digunakan sebagai Customer Service, Peran customer service sangat di perlukan dalam melayani pemesanan pelanggan [6]. Sifat dari sistem ChatBot memiliki kesamaan dengan peralatan pemantau dan pengendali jarak untuk peralatan listrik jarak jauh yang efektif dan efisien, dengan menggunakan telepon seluler (tanpa kabel) yang menyediakan layanan SMS, dimana fasilitas SMS tersebut memberikan kemudahan untuk bertukar informasi (berbasis teks) pada jarak jauh [7].

\subsection{Artificial Intelligence Markup Language}

AIML adalah singkatan dari Artificial Intelligence Markup Language yang berbasis XML dengan dimaksudkan untuk membuat aplikasi kecerdasan buatan. AIML merupakan bahasa yang diterapkan pada A.L.I.C.E ChatBot dengan mengimplementasikan beberapa konsep penalaran yang ada pada Artificial Intelligence. Unsur-unsur AIML terdiri dari beberapa tag yang memiliki fungsi masing-masing untuk kalimat dalam knowledge basenya. Unsur tag yang ada akan mendefenisikan bentuk kalimat tertentu dengan jawaban tertentu dalam knowledge base. Sedangkan ALICE (Artificial Linguistic Internet Computer Entity) adalah aplikasi berdasarkan bahasa markup yang disebut AIML (Artificial Intelligence Markup Language). Bahasa ini terstruktur file teks yang menyediakan pola dan respon yang diharapkan [8].

Contoh struktur AIML:

\begin{tabular}{|c|c|c|}
\hline \multicolumn{3}{|c|}{\begin{tabular}{|c|}
$<$ category $>$ \\
$<$ pattern $>$ HALO $</$ pattern $>$ \\
<template $>$ \\
$<$ random $>$ \\
$\quad<$ li $>$ Hai $</$ li $>$ \\
$<$ li $>$ Halo juga $</$ li $>$ \\
$</$ random $>$ \\
$</$ template $>$ \\
$</$ category $>$ \\
\end{tabular}} \\
\hline \multicolumn{3}{|c|}{ Tabel 1. Tabel Tag AIML } \\
\hline No & Tag & Fungsi \\
\hline 1 & $<$ aiml $></$ aiml $>$ & $\begin{array}{c}\text { Mendefiniskan awal } \\
\text { dan akhir }\end{array}$ \\
\hline 2 & $<$ category $></$ category $>$ & $\begin{array}{l}\text { Mendefinisikan unit } \\
\text { of knowledge }\end{array}$ \\
\hline 3 & $\langle$ pattern $></$ pattern $>$ & Matching part \\
\hline 4 & $<$ template $></$ template $>$ & Returning part \\
\hline 5 & $<$ star/> & Mengambil data * \\
\hline 6 & $<$ random $></$ random $>$ & $\begin{array}{l}\text { Memilih template } \\
\text { secara random }\end{array}$ \\
\hline
\end{tabular}

\subsection{Natural Language Processing}

Natural Language Processing (NLP) adalah salah satu bidang ilmu komputer, yang terkait dengan kecerdasan buatan, dan bahasa (linguistik) yang mana membahas dengan interaksi antara komputer dan bahasa alami manusia, seperti halnya bahasa Indonesia, bahasa Inggris, bahkan bahasa Jawa. Dalam arti luas untuk mencakup segala jenis manipulasi komputer dari bahasa alami. Lebih lanjut, bisa sesederhana menghitung frekuensi kata untuk membandingkan berbagai gaya penulisan. Di sisi lain, NLP melibatkan "pemahaman" ucapan manusia yang lengkap, setidaknya mampu memberikan tanggapan yang bermanfaat bagi pengguna [9].

Teknologi berbasis NLP menjadi semakin luas. Sebagai contoh, telepon dan komputer genggam mendukung teks prediksi dan pengenalan tulisan tangan; mesin pencari web memberikan akses ke informasi yang dikunci dalam teks yang tidak terstruktur, mesin terjemahan memungkinkan kita untuk mengambil teks yang ditulis dalam bahasa Cina dan membacanya dalam bahasa Spanyol. Dengan menyediakan antarmuka manusia-mesin yang lebih alami, dan akses yang lebih canggih untuk mengakses informasi yang tersimpan, pemrosesan bahasa telah memainkan peran sentral dalam masyarakat informasi multibahasa [9]. 


\section{METODE PENELITIAN}

\subsection{Blok Diagram}

Pada Gambar 1 user harus membuka aplikasi whatsapp dan untuk bisa berbincang Jika sudah, maka user sudah bisa bertukar pesan dengan chatbot. Ketika user mengirim pesan, sistem akan membaca pesan yang tersebut dan melakukan normalisasi untuk memudahkan sistem dalam memahami makna pesan yang diterima.dengan chatbot, user harus menyimpan nomor milik chatbot.

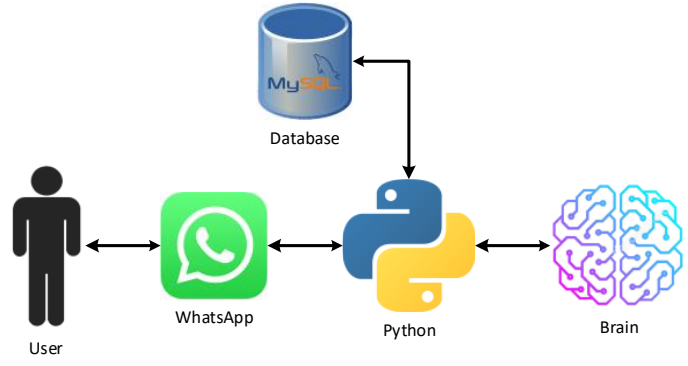

Gambar 1. Blok Diagram ChatBot

Setelah itu barulah pesan dicocokan dengan Knowledge Base atau Brain yang berisikan kumpulan Pattern. Setelah diketahui Pattern yang sesuai, sistem mulai mengambil informasi yang berada di dalam database dan mengirimkannya kembali ke user sebagai pesan balasan.

\subsection{Flowchart Sistem}

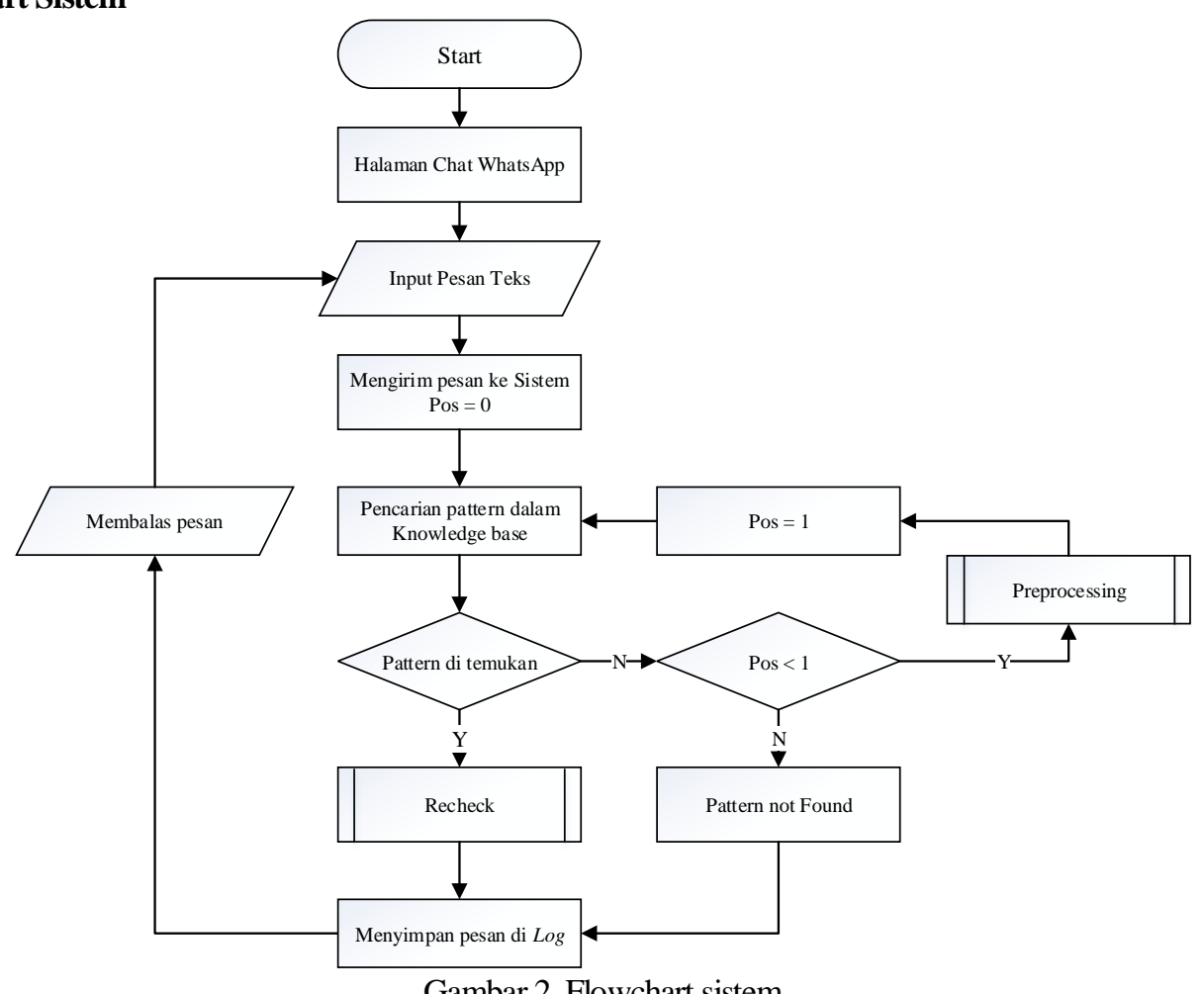

Gambar 2. Flowchart sistem

Gambar 2 menjelaskan bahwa setelah masuk ke halaman WhatsApp dan mengirim pesan ke kontak ChatBot, pesan akan diterima oleh sistem dan kemudian akan dicocokan dengan pattern yang sudah ada di Knowledge Base. Jika pattern tidak dikenali dan belum melakukan preprocessing sebelumnya, sistem akan melakukan proses preprocessing untuk mengolah pesan untuk mempermudah brain dalam mencocokkan pesan dengan pattern, dan jika pattern ditemukan, maka sistem akan masuk ke tahap Recheck untuk mengolah informasi dari pesan yang diterima dan mengubah informasi tersebut menjadi kalimat dan mengirimnya kembali sebagai pesan balasan. 


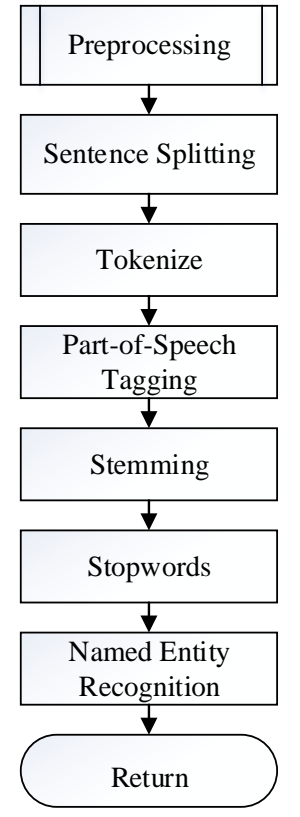

Gambar 3. Flowchart sistem

Gambar 3 menjelaskan bahwa setelah pesan yang diterima oleh sistem pertama-tama akan memecah kalimat (Sentence Splitting) apabila ditemukan tanda baca “.”, “!” dan “?” di dalam pesan tersebut. Kemudian dari sebuah kalimat tersebut, akan di pecah lagi per-kata atau yang disebut dengan Tokenize. Dari kumpulan kata yang didapat akan di cek, apakah kata tersebut masuk ke kata kerja (Verb), kata benda (Noun), kata sifat (Adjective) dan lainlain, tahap ini disebut dengan Part-of-Speech Tagging. Mengabaikan hasil POS-Tagging, berikutnya masuk ke tahap Stemming yang berfungsi untuk mengubah kata hasil Tokenize menjadi kata dasarnya. Selanjutnya pada Stopwords, hasil dari Stemming akan di cek, apakah kata tersebut termasuk kata penting yang akan membantu sistem dalam memahami intruksi dalam pesan tersebut. Terakhir pada tahap Named Entity Recognition (NER), pesan dari proses POS-Tagging akan identifikasi apakah kata tersebut nama seseorang, sebuah organisasi, sebuah angka dan sebagainya.

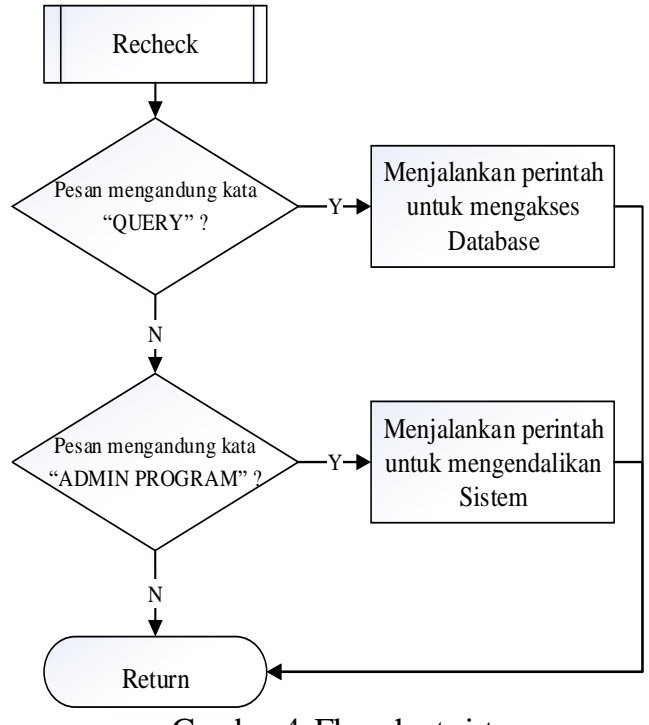

Gambar 4. Flowchart sistem

Pada tahap Recheck, hasil dari pencocokan pesan dengan pattern akan di cek ulang untuk menemukan keyword yang bisa dianggap sebagai intruksi dalam mengendalikan sistem. Gambar 4 menunjukkan bahwa dija pesan hasil proses tersebut memiliki keyword "QUERY" maka pesan tersebut memberikan intruksi untuk mengelola informasi pada database seperti Read, Update dan Delete. Namun jika ditemukan keyword "ADMIN PROGRAM" maka pesan tersebut mengintruksikan sistem untuk mengatur kondisi ChatBot seperti menjeda proses chatting, sampai menghentikan program.

\subsection{DFD Level 0}

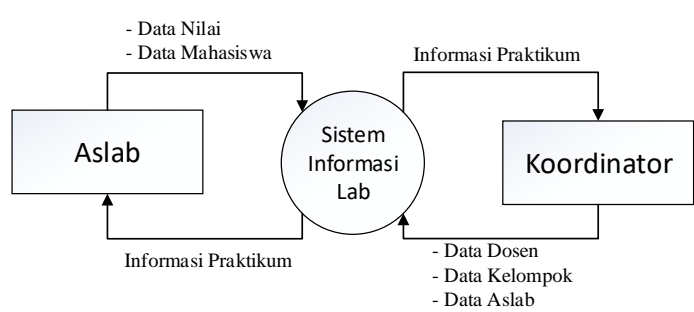

Gambar 5. DFD level 0

Pada Gambar 5 menjelaskan alur diagram level 0, dimana Aslab dapat menambahkan data baru berupa Mahasiswa dan Nilai, sedangkan Koordinator dapat menambahkan data Aslab. Kelompok dan Dosen yang kemudian disimpan oleh sistem untuk di proses nantinya. 


\subsection{DFD Level 1}

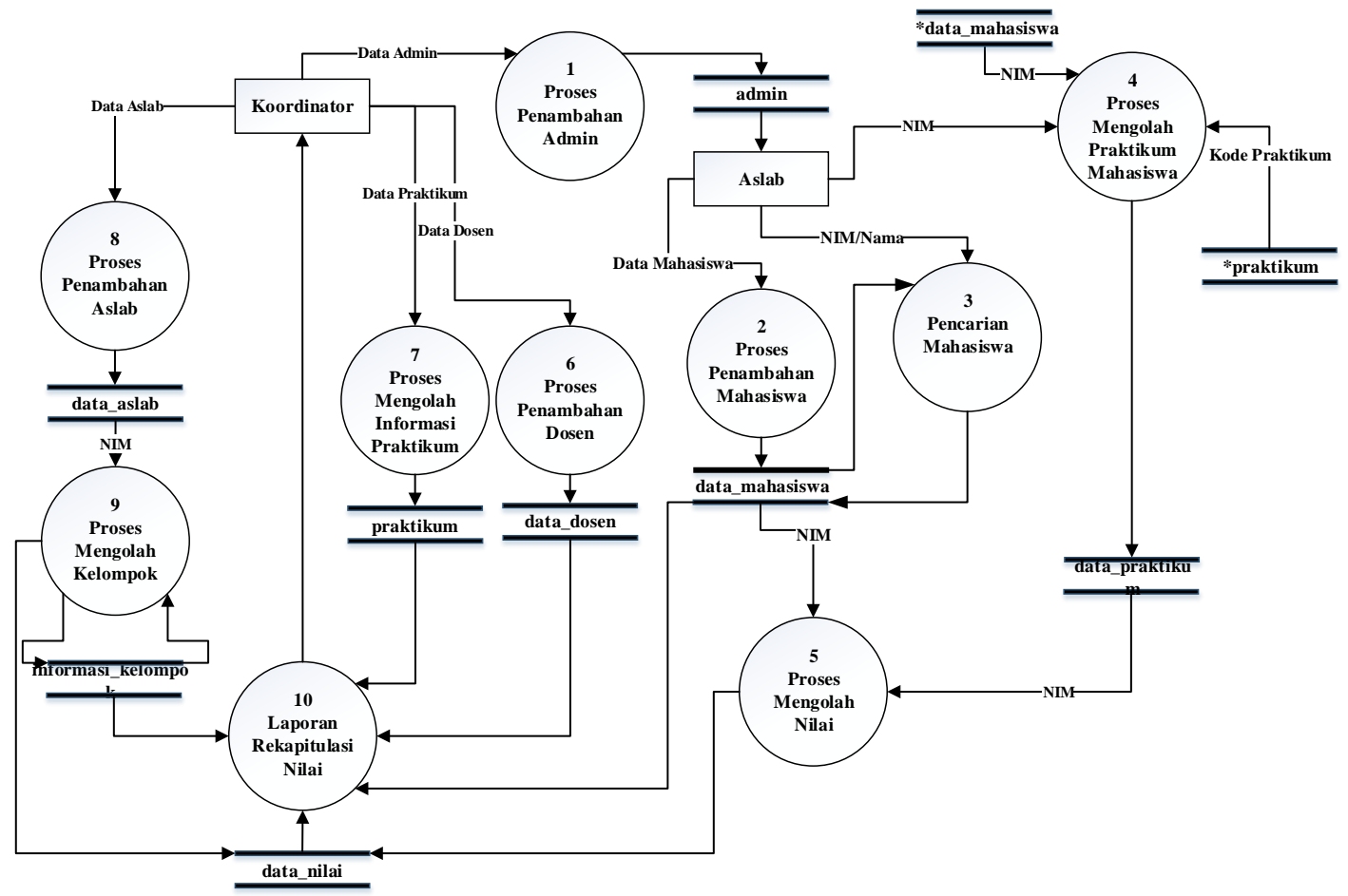

Gambar 6. DFD Level 1

Pada Gambar 6 menjelaskan alur diagram level 1, dimana Koordinator dapat menambahkan akun Aslab sebagai Admin yang memiliki hak untuk menambahkan mengolah (lihat, tambah dan ubah) data Mahasiswa dan Nilai yang kemudian akan disimpan oleh sistem. Koordinator memiliki hak khusus dalam menghapus data mengolah data Dosen, Informasi Praktikum, Informasi Aslab, Kelompok dan cetak Laporan Rekapitulasi Nilai.

\section{HASIL DAN PEMBAHASAN}

\subsection{Halaman Mahasiswa}

\section{Zero v.1.0.0}

Halaman Ini Menyediakan Informasi Berupa Daftar Mahasiswa, Kelompok, Praktikum \& Nilai

\section{+ tambah Data Q PEncarian}

\begin{tabular}{|c|c|c|c|c|}
\hline \multirow{2}{*}{$\begin{array}{l}\text { NIM } \\
\text { Mahasiswa }\end{array}$} & \multirow{2}{*}{$\begin{array}{l}\text { Nama Mahasiswa } \\
\text { FARIS ASRORY }\end{array}$} & \multicolumn{3}{|c|}{ Actions } \\
\hline & & $\begin{array}{c}\text { 国 } \\
\text { View }\end{array}$ & $\begin{array}{c}\text { E } \\
\text { Edit }\end{array}$ & $\stackrel{\circledast}{\circledR}$ \\
\hline 1318073 & $\begin{array}{l}\text { ZAKIEY CAHYAARDI } \\
\text { WAHANA }\end{array}$ & $\begin{array}{c}\text { 圄 } \\
\text { View }\end{array}$ & $\begin{array}{c}E \\
\text { Edit }\end{array}$ & $\stackrel{\circledast}{\otimes}$ \\
\hline 1318078 & FIKRIADI SAKRANI & $\begin{array}{c}\text { 圊 } \\
\text { View }\end{array}$ & $\begin{array}{c}\text { E } \\
\text { Edit }\end{array}$ & $\stackrel{\circledast}{\otimes}$ \\
\hline 1318107 & ROLAND MARVELOUS ABI & $\begin{array}{c}\text { 国 } \\
\text { View }\end{array}$ & $\begin{array}{c}G \\
\text { Edit }\end{array}$ & $\stackrel{\circledast}{\otimes}$ \\
\hline 1318189 & $\begin{array}{l}\text { NOVAL PRADANA SADIAN } \\
\text { HURI }\end{array}$ & $\begin{array}{c}\text { 国 } \\
\text { View }\end{array}$ & $\begin{array}{c}\Xi \\
\text { Edit }\end{array}$ & $\stackrel{\circledast}{\otimes}$ \\
\hline
\end{tabular}

Gambar 7. Halaman Mahasiswa

Pada halaman Praktikum, user yang sudah login dapat melihat informasi para praktikan yang terdiri dari NIM dan Nama. Adapula Actions yang digunakan untuk mengolah data praktikan, yang terdiri dari View, Edit dan Delete. Namun untuk Delete hanya bisa diakses oleh Koordinator. Terdapat pula fitur pagging untuk memudahkan dalam berpindah halaman.

\subsection{Halaman Nilai}

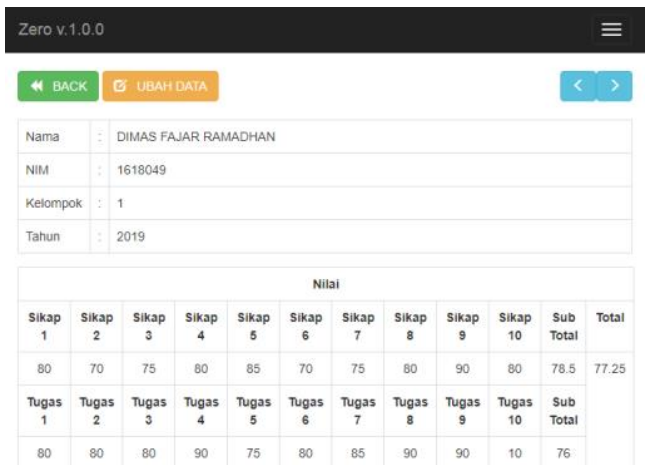

Gambar 8. Halaman Nilai

Setelah menggunakan fitur view pada halaman praktikum, user akan dibawa ke halaman baru yang berfungsi untuk mengatur informasi nilai praktikum yang diikuti oleh praktikan yang terkait. Terdapat 
fitur view data nilai yang digunakan untuk melihat data nilai dari praktikum yang diikuti oleh praktikan.

\subsection{ChatBot \\ 1. Validasi Akun}

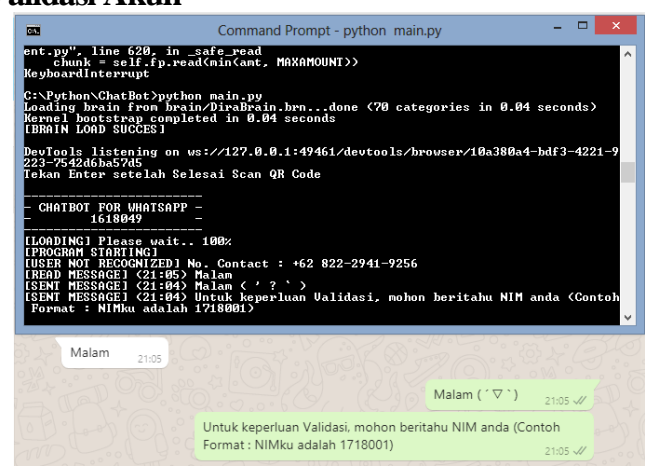

Gambar 9. Validasi akun

Pengujian program ChatBot ini didapatkan dari penggabungan 4 komponen yang memiliki tugas berbeda-beda yaitu sebagai penghubung sistem dengan WhatsApp, MySQL, lalu pembuatan brain menggunakan $A I M L$ dan sebagai pengolah kata menggunakan NLP. Pada Gambar 10 menunjukkan bahwa pesan yang diterima dikenali pattern-nya dan mengambil jawaban dari template-nya. Kemudian, apabila pengguna belum pernah melakukan kontak dengan ChatBot, maka secara otomatis akan diminta informasi nim dan nama panggilan seperti yang ditampilkan pada Gambar 9 dan 10.

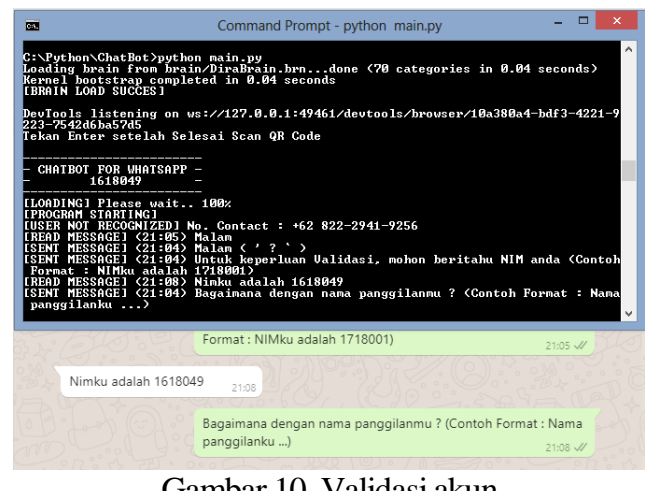

\section{Request Data}

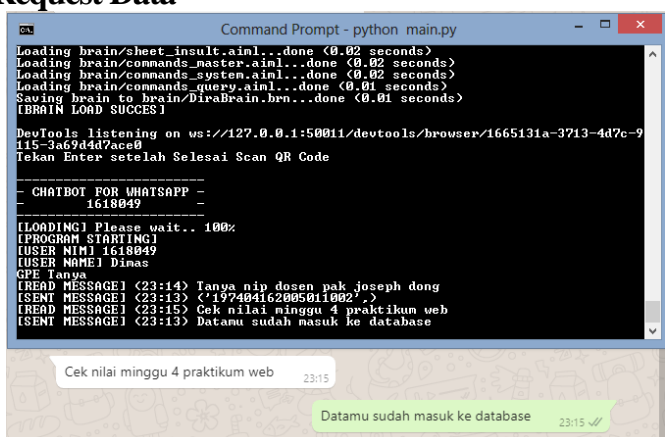

Gambar 11. Request Data
Pada Gambar 11 menunjukkan, setelah ditemukan pattern yang sesuai dan didalam templatenya didapati sebuah keyword yang akan menjalankan proses yaitu request informasi dari database, sistem akan mengambil infromasi berdasarkan kriteria yang diminta. Dapat pula request informasi NIP dosen seperti yang ditunjukkan pada gambar 12 .

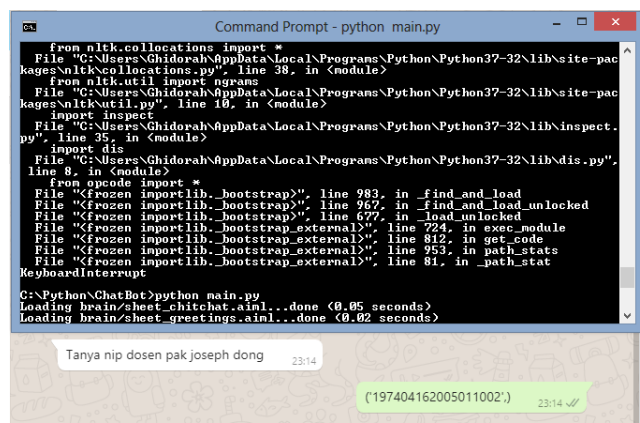

Gambar 12. Request Data NIP Dosen

\section{Input Data}

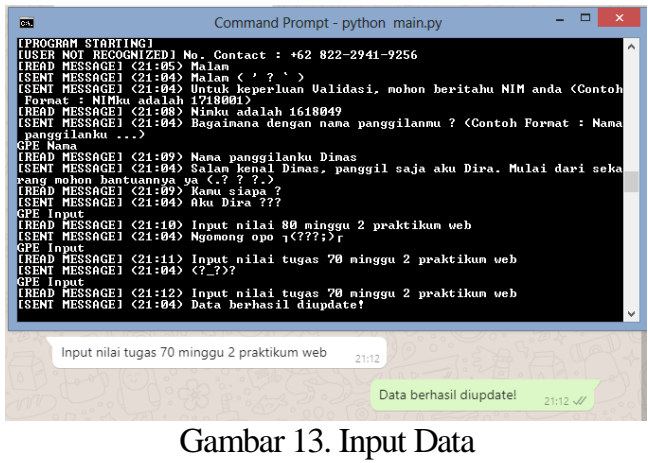

Pada Gambar 13 sama seperti request data, disini sistem menerima data untuk disimpan di database. Namun fitur ini hanya bisa diakses oleh pengguna yang memiliki role Aslab atau Master. Jika pengguna tidak memiliki role tersebut, maka sistem akan merespon seperti pada Gambar 14.

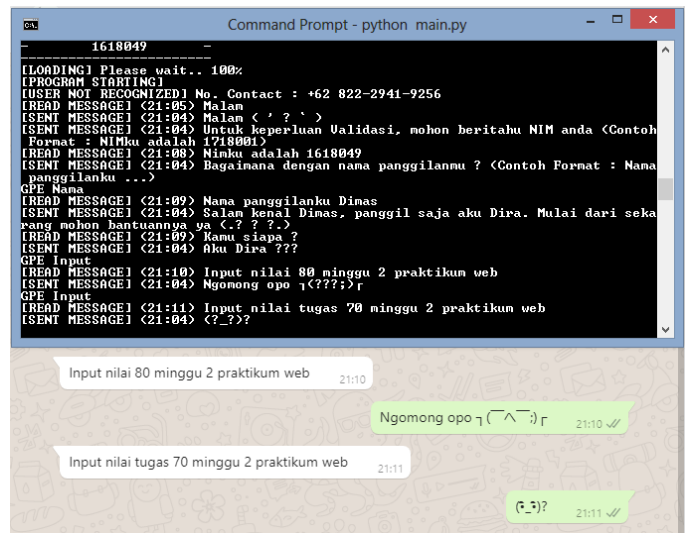

Gambar 14. Input Data tanpa role 


\subsection{Pengujian Fungsional}

Pengujian fungsional sistem dilakukan untuk menguji fitur-fitur yang ada pada sistem Sistem Informasi Lab dan Chatbot. Hasil pengujian fungsional Sistem Informasi Lab ditunjukan dalam Tabel 2 sedangkan Hasil pengujian fungsional Sistem ChatBot ditunjukkan dalam Tabel 3.

Tabel 2. Hasil pengujian fungsional Sistem Informasi Laboratorium

\begin{tabular}{|c|c|c|c|}
\hline No. & Fungsi yang diuji & Berhasil & Gagal \\
\hline 1 & Login & $\checkmark$ & - \\
\hline 2 & $\begin{array}{l}\text { Halaman Praktikum } \\
\text { a. Tambah Data Mahasiswa } \\
\text { b. Edit Data Mahasiswa } \\
\text { c. Delete Data Mahasiswa } \\
\text { d. View informasi Praktikum } \\
\text { e. Tambah informasi Praktikum } \\
\text { f. Edit informasi Praktikum } \\
\text { g. Delete informasi Praktikum } \\
\text { h. View data Nilai } \\
\text { i. Ubah data Nilai }\end{array}$ & $\begin{array}{l}\checkmark \\
\checkmark \\
\checkmark \\
\checkmark \\
\checkmark \\
\checkmark \\
\checkmark \\
\checkmark \\
\checkmark\end{array}$ & $\begin{array}{l}- \\
- \\
- \\
- \\
- \\
- \\
- \\
- \\
-\end{array}$ \\
\hline 3 & $\begin{array}{l}\text { Halaman Aslab } \\
\text { a. Tambah Data Aslab } \\
\text { b. Edit Data Aslab } \\
\text { c. Delete Data Aslab } \\
\text { d. View informasi Kelompok } \\
\text { e. Tambah informasi Kelompok } \\
\text { f. Edit informasi Kelompok } \\
\text { g. Delete informasi Kelompok }\end{array}$ & $\begin{array}{l}\checkmark \\
\checkmark \\
\checkmark \\
\checkmark \\
\checkmark \\
\checkmark \\
\checkmark \\
\checkmark\end{array}$ & $\begin{array}{l}- \\
- \\
- \\
- \\
- \\
- \\
-\end{array}$ \\
\hline 4 & $\begin{array}{l}\text { Halaman Sistem } \\
\text { a. Sign Up Function } \\
\text { b. Print Rekapitulasi Nilai } \\
\text { c. Reset Data Mahasiswa } \\
\text { d. Reset Data Praktikum } \\
\text { e. Reset Data Nilai } \\
\text { f. Reset Data Kelompok }\end{array}$ & $\begin{array}{l}\checkmark \\
\checkmark \\
\checkmark \\
\checkmark \\
\checkmark \\
\checkmark\end{array}$ & $\begin{array}{l}- \\
- \\
- \\
- \\
- \\
-\end{array}$ \\
\hline
\end{tabular}

Tabel 3. Hasil pengujian fungsional Sistem Informasi Laboratorium

\begin{tabular}{|c|l|l|c|}
\hline No & \multicolumn{1}{|c|}{ Fitur } & \multicolumn{1}{|c|}{ Pengujian } & Hasil \\
\hline 1 & Validasi User & $\begin{array}{l}\text { Input NIM } \\
\text { Input Nama Panggilan }\end{array}$ & Sesuai \\
\hline 2 & Cek Nilai & Input Minggu \& Praktikum & Sesuai \\
\hline 3 & Input Nilai & $\begin{array}{l}\text { Input NIM, Minggu, } \\
\text { Praktikum \& Nilai }\end{array}$ & Sesuai \\
\hline 4 & $\begin{array}{l}\text { Cek NIP } \\
\text { Dosen }\end{array}$ & Input Nama Dosen & Sesuai \\
\hline
\end{tabular}

Dari pengujian Fungsional, didapatkan hasil berupa fungsi inti dari Web Sistem Informasi Laboratorium berjalan dengan baik, begitu pula dengan fungsi dasar milik program ChatBot, meskipun koneksi Internet akan mempengaruhi kinerja dari ChatBot.

Tabel 4. Hasil pengujian percakapan

\begin{tabular}{|c|l|c|}
\hline No & \multicolumn{1}{|c|}{ Pengujian } & Hasil \\
\hline 1 & $\begin{array}{l}\text { Percakapan Ringan : Salam, } \\
\text { Canda, Basa-basi }\end{array}$ & $71.67 \%$ \\
\hline 2 & $\begin{array}{l}\text { Perintah : Cek Nilai, Cek NIP } \\
\text { Dosen \& Input Nilai }\end{array}$ & $85.33 \%$ \\
\hline
\end{tabular}

Berdasarkan hasil pengujian fungsional yang telah dilakukan menggunakan 30 skenario, didapatkan sebanyak $71.67 \%$ sistem dapat memahami pesan yang diterima untuk percakapan ringan dan $85.33 \%$ sistem memahami pesan berupa perintah atau request yang berhubungan dengan data yang berada pada database.

\subsection{Pengujian Pada Browser}

Pada tahapan pengujian browser ini, dilakukan pengujian menggunakan tiga browser. Dimana pengujian ini dilakukan untuk mengetahui kecocokan browser dengan web Sistem Informasi Laboratorium. Dan berikut adalah tabel hasil pengujian dari pembuatan web Sistem Informasi Laboratorium menggunakan tiga browser yang ditunjukkan pada Tabel 5.

Tabel 5. Hasil pengujian Browser

\begin{tabular}{|l|c|c|c|}
\hline \multirow{2}{*}{\multicolumn{1}{|c|}{ Proses }} & \multicolumn{3}{c|}{ Browser } \\
\cline { 2 - 4 } & GC & MF & IE \\
\hline Login & $\checkmark$ & $\checkmark$ & $\checkmark$ \\
\hline Halaman Praktikum & $\checkmark$ & $\checkmark$ & $\checkmark$ \\
\hline Halaman Aslab & $\checkmark$ & $\checkmark$ & $\checkmark$ \\
\hline Halaman Dosen & $\checkmark$ & $\checkmark$ & $\checkmark$ \\
\hline Halaman Sistem & $\checkmark$ & $\checkmark$ & $\checkmark$ \\
\hline Logout & $\checkmark$ & $\checkmark$ & $\checkmark$ \\
\hline
\end{tabular}

Keterangan:

$\mathrm{GC}=$ Google Chrome v79

$\mathrm{MF}=$ Mozilla Firefox v70

IE $=$ Internet Explorer v10

Pada hasil pengujian web Sistem Informasi Laboratorium dengan menggunakan 3 browser yang berbeda, semua tampilan dan fungsi pada web berjalan dengan baik. Namun pada Mozilla Firefox terdapat sebuah delay dalam menampilkan CSS dan $J S$ milik Web Sistem Informasi Laboratorium, sehingga Nampak transisi antara halaman polos menjadi halaman dengan CSS. Sedangkan untuk program ChatBot hanya bisa dijalankan menggunakan Google Chrome dikarenakan driver yang digunakan hanya untuk browser tersebut.

\section{KESIMPULAN DAN SARAN \\ 5.1 Kesimpulan}

Dari hasil pembuatan web Sistem Informasi Laboratorium dan program ChatBot, maka diambil kesimpulan sebagai berikut:

1. Pengujian program ChatBot menunjukkan bahwa kombinasi antara AIML sebagai brain dan pengimplementasian NLP untuk mengolah sebuah kalimat menghasilkan kemudahan sistem dalam memahami perintah yang tidak tersedia pada brain.

2. ChatBot bisa melakukan percakapan dengan user melalui media komunikasi WhatsApp, sekaligus 
menyimpan informasi user menggunakan Session disaat melakukan validasi akun.

3. Pengembangan Website Sistem Informasi Laboratorium dan Program ChatBot yang telah dibuat menghasilkan sebuah Sistem yang saling terhubung, dimana Website Sistem Informasi Laboratorium digunakan sebagai media rekapitulasi nilai, dan dengan bantuan ChatBot Aslab bisa mengisi nilai melalui WhatsApp sehingga tidak ada lagi pengisian nilai secara manual pada kertas. Ditambah praktikan bisa mengetahui informasi tentang lab langsung melalui ChatBot tersebut.

\subsection{Saran}

Untuk pengembangan kedepan yang lebih baik, web Sistem Informasi Laboratorium dan program Chatbot ini memiliki beberapa saran, yaitu:

1. Untuk pengembangan lebih lanjut pada web Sistem Informasi Laboratorium hendaknya ditambahkan fitur penjadwalan.

2. Untuk pengembangan lebih lanjut pada brain ChatBot hendaknya ditambahkan lebih banyak lagi pattern supaya membuat percakapan dengan user lebih beragam, sekaligus fungsi dimana sistem dapat menggunakan riwayat percakapan sebagai informasi tambahan tentang user.

3. Penambahan algoritma pada sistem ChatBot untuk men-generate XPATH secara otomatis, dikarenakan jalur XPATH bisa sewaktu-waktu berubah.

\section{DAFTAR PUSTAKA}

[1] Hakiki, I., 2018. PENERAPAN METODE FUZZY PADA GAME 3D "SIMPLE $W A Y ”$ (Institut Teknologi Nasional Malang).

[2] Dedy Irawan, J., Handoko, F. and Adriantatri, E., 2019. Ruang Kuliah Pintar Pemantau
Tingkat Efektivitas Pembelajaran Yang Dapat Mendeteksi Mahasiswa Bosan Dan Mengantuk. In Seminar Nasional Inovasi dan Aplikasi Teknologi di Industri.

[3] Mahdiyah, E. and Andriyani, Y., 2013. Analisa Algoritma Pemahaman Kalimat Pada ALICE ChatBot Dengan Menggunakan Artificial Intelligence Markup Language (AIML). Prosiding SEMIRATA 2013, 1(1).

[4] Pamungkas, W.C., 2011. Internet Relay Chat BoT Dengan Menggunakan Artificial Intelligent Markup Languange (Aiml). Jurnal Informatika, 4(1).

[5] Azwary, F., Indriani, F. and Nugrahadi, D.T., 2016. Question Answering System Berbasis Artificial Intelligence Markup Language Sebagai Media Informasi. KLIK-KUMPULAN JURNAL ILMU KOMPUTER, 3(1), pp.48-60.

[6] Imamah, F. and Dores, A., 2018. Aplikasi Chatbot (Milki Bot) Yang Terintegrasi Dengan Web Cms Untuk Customer Service Pada UKM Minsu. Jurnal Cendikia, 16(2 Oktober), pp.100106.

[7] Adi Jatmiko, P., Noertjahjono, S. and Sotyohadi, S., 2012. Pembuatan Sisem Pengendali On/Off Peralatan Listrik via SMS Dengan Fasilitas Konfigurasi Nomor HP Berbasis ATMEGA16. Jurnal Elektro ELTEK, 3(1).

[8] Booth, J. D. (2018). Natural Language Processing Succintly. Morrisville, NC: Syncfusion

[9] Bind, S., Etc (2009). Natural Language Processing with Python. Sebastopol. O'Reilly Meddia Inc. 